\title{
ANÁLISE DE REDES SOCIAIS DE COLABORAÇÃO EM BANCAS DE DEFESA DE DOUTORADO NA PÓS-GRADUAÇÃO EM CIÊNCIA DA INFORMAÇÃO
}

\author{
Flávia de Araújo Telmo \\ Mestrado em Ciência da Informação - PPGCI - UFPB \\ flaviaaraujo.t@gmail.com \\ Alzira Karla Araújo da Silva \\ Orientadora \\ Doutora em Ciência da Informação \\ Professora do DCI e do PPGCI-UFPB \\ Emeide Nóbrega Duarte \\ Coorientadora \\ Doutora em Administração \\ Professora do DCI e do PPGCI-UFPB
}

\section{Resumo}

As redes sociais de produção do conhecimento, as formas de colaboração entre pesquisadores, a constituição de redes e a dinâmica das interações sociais, tornam-se assuntos de interesse de comunidades científicas que lidam com a informação. Analisar a participação em bancas de defesa constitui oportunidade de conhecer as características inerentes aos atores de uma rede social em que estão vinculados, as pesquisas realizadas, os fatores que influenciam as relações, os interesses temáticos das pesquisas científicas, a interligação entre programas e instituições e o modo como as áreas se consolidam e ampliam as parcerias no compartilhamento do conhecimento para o desenvolvimento científico, principalmente pela interdisciplinaridade. Nesse contexto, o estudo analisa a rede social de colaboração em bancas de defesa de doutorado na Pós-graduação em Ciência da Informação da Universidade Federal da Paraíba. Metodologicamente, fundamentase a partir dos objetivos como pesquisa descritiva e documental, com abordagem quantitativa e qualitativa. Para a coleta de dados utilizou-se de formulários; o software Excel para elaboração de planilhas; o Vantage Point para mineração dos dados; o Ucinet e Netdraw para elaborar as matrizes e os grafos. Os resultados foram analisados sob a perspectiva da metodologia de análise de redes sociais. A análise dessas redes de colaboração resultou na caracterização dos membros e da estrutura de defesa das teses, bem como na compreensão das relações ator-rede estabelecidas nas bancas de defesas do doutorado do PPGCI/UFPB no período de 2015 a 2018.1. Identifica que a interação e a comunicação dialógica entre os membros nas bancas de doutorado no referido Programa efetiva-se sob regras formais e interesses de pesquisas inerente a atuação destes membros, linhas de pesquisas e formação acadêmica. Ressalta a constituição de redes com relações de pesquisadores com programas externos, bem como instituições nacionais e interinstitucionais. Conclui que a rede de colaboração em bancas de defesa de doutorado no PPGCI/UFPB permite o compartilhamento da informação e a ampliação de conhecimento em redes entre esses atores e a oportunidade de novas parcerias colaborativas.

Palavras-chave: Redes Sociais de Colaboração. Análise de Redes Sociais. Redes de Colaboração. Ciência da Informação. Bancas de doutorado. Programa de Pós-Graduação em Ciência da Informação. 